\title{
PREVALENCE OF PJK AFTER ARTHRODESIS IN PATIENTS WITH NEUROMUSCULAR SCOLIOSIS IN THE SECOND POSTOPERATIVE YEAR
}

\author{
PREVALÊNCIA DE PJK APÓS ARTRODESE EM PACIENTES COM ESCOLIOSE \\ NEUROMUSCULAR NO SEGUNDO ANO DE PÓS-OPERATÓRIO
}

\section{PREVALENCIA DE PJK DESPUÉS DE ARTRODESIS EN PACIENTES CON ESCOLIOSIS NEUROMUSCULAR EN EL SEGUNDO AÑO DE POSTOPERATORIO}

\author{
Rodrigo Magalhães Falcão, ${ }^{1,2}$ Kaio Rodrigo Barreto Ramiro, ${ }^{1,2}$ Mauricio Coello Lima, ${ }^{1,2}$ Ivan Guidolin Veiga, ${ }^{1,2}$ Marcelo Italo Risso Neto, ${ }^{1}$ \\ Mauricio Antonelu lehoczkı, ${ }^{2}$ Alexander Junoueira Rossato, ${ }^{2}$ Paulo Tadeu Maia Cavali ${ }^{1,2}$
}

1. Universidade Estadual de Campinas (Unicamp), Department of Orthopedics and Traumatology, Campinas, SP, Brazil.

2. Associação de Assistência à Criança Deficiente (AACD), Scoliosis Group, São Paulo, SP, Brazil.

\begin{abstract}
Objective: The primary objective of this study was to analyze the prevalence of PJK in patients with neuromuscular scoliosis submitted to posterior spinal arthrodesis with instrumentation. Proximal junctional kyphosis (PJK) is a frequent phenomenon that, due to its importance, began to be studied by several authors, who laid the foundations for the radiographic definition and possible risk factors for its occurrence after long spinal arthrodesis with instrumentation. Despite the large number of PJK studies, most were related to the occurrence of adolescent idiopathic scoliosis, adult deformity and early-onset scoliosis, with few being targeted to patients with congenital and neuromuscular scoliosis. Methods: In this study, data from electronic medical records of patients with neuromuscular scoliosis who underwent posterior arthrodesis with instrumentation between the years 2014 and 2016 were analyzed. Information on age, gender, pathology and radiographic measurements were extracted from this sample at the $2^{\text {nd }}$ and $24^{\text {th }}$ postoperative months. Results: A total of 39 patients with neuromuscular scoliosis were analyzed. The sample was predominantly male (58.87\%) and the mean age was 14.05 years. PJK occurred in 18 patients during the two years following surgery, with a prevalence of $46.15 \%$. The incidence of PJK in the $2^{\text {nd }}$ and $24^{\text {th }}$ postoperative months was $23.1 \%$ and $30 \%$, respectively. Conclusions: A prevalence of PJK of $46.15 \%$ was found in patients with neuromuscular scoliosis treated surgically with posterior instrumentation after two years of follow-up, as compared to previous results. Level of Evidence III; Cross-sectional observational study.
\end{abstract}

Keywords: Kyphosis; Scoliosis; Spine.

\section{RESUMO}

Objetivo: O objetivo primário deste estudo foi analisar a prevalência de PJK nos pacientes com escoliose neuromuscular, submetidos à artrodese da coluna vertebral por via posterior com instrumentação. A cifose juncional proximal (PJK) é um fenômeno frequente que, devido à sua importância, passou a ser estudado por diversos autores, os quais lançaram as bases da definição radiográfica e possíveis fatores de risco de ocorrência depois de artrodese longa da coluna vertebral com instrumentação. Apesar da grande quantidade de estudos sobre PJK, a maioria foi relacionada quanto à ocorrência na escoliose idiopática do adolescente, na deformidade do adulto e na escoliose de início precoce, sendo poucos direcionados a pacientes com escoliose congênita e neuromuscular. Métodos: Neste estudo foram analisados dados de prontuários eletrônicos de pacientes com escoliose neuromuscular submetidos à artrodese por via posterior com instrumentação, entre os anos de 2014 e 2016. Dessa amostra, foram extraídas informações pertinentes a idade, gênero, patologia e medidas radiográficas no $2^{\circ}$ e $24^{\circ}$ mês de pós-operatório. Resultados: Um total de 39 pacientes com escoliose neuromuscular foi analisado. Na amostra houve predomínio de pacientes do sexo masculino (58,87\%) e a média de idade foi de 14,05 anos. A PJK ocorreu em 18 pacientes no decorrer de dois anos de pós-operatório, com prevalência de 46,15\%. A incidência de PJK no $2^{\circ}$ e $24^{\circ}$ mês de pós-operatório foi de $23,1 \%$ e $30 \%$, respectivamente. Conclusões: Foi encontrada prevalência de 46,15\% de PJK em pacientes com escoliose neuromuscular tratados cirurgicamente com instrumentação por via posterior depois de dois anos de seguimento, confrontado resultados anteriores. Nível de Evidência III; Estudo observacional analítico transversal.

Descritores: Cifose; Escoliose; Coluna Vertebral.

\section{RESUMEN}

Objetivo: El objetivo primario de este estudio fue analizar la prevalencia de PJK en los pacientes con escoliosis neuromuscular, sometidos a artrodesis de la columna vertebral por vía posterior con instrumentación. La cifosis de unión proximal (PJK) es un fenómeno frecuente que, debido a su importancia, pasó a ser estudiado por diversos autores, los cuales lanzaron las bases de la definición radiográfica y posibles factores de riesgo de ocurrencia después de artrodesis larga de la columna vertebral con instrumentación. A pesar de la gran cantidad de estudios sobre PJK, la mayoría fue relacionada cuanto a la ocurrencia en la escoliosis idiopática del adolescente, en la deformidad del adulto y en la escoliosis de inicio precoz, siendo pocos direccionados a pacientes con escoliosis congénita y neuromuscular. Métodos: 
En este estudio se analizaron datos de prontuarios electrónicos de pacientes con escoliosis neuromuscular sometidos a artrodesis por vía posterior con instrumentación, entre los años 2014 y 2016. De esa muestra se extrajeron informaciones pertinentes a edad, género, patología y medidas radiográficas en el $2^{\circ}$ y $24^{\circ}$ mes de postoperatorio. Resultados: Fue analizado un total de 39 pacientes con escoliosis neuromuscular. En la muestra hubo predominio de pacientes del sexo masculino (58,87\%) y el promedio de edad fue de 14,05 años. La PJK ocurrió en 18 pacientes en el transcurso de 2 años de postoperatorio, con prevalencia de $46,15 \%$. La incidencia de PJK en el $2^{\circ}$ y $24^{\circ}$ mes de postoperatorio fue de 23,1\% y 30\%, respectivamente. Conclusiones: Se encontró prevalencia de 46,15\% de PJK en pacientes con escoliosis neuromuscular tratados quirúrgicamente con instrumentación por vía posterior después de 2 años de seguimiento, confrontando resultados anteriores. Nivel de evidencia III; Estudio observacional analítico transversal.

Descriptores: Cifosis; Escoliosis; Columna Vertebral.

\section{INTRODUCTION}

Proximal junctional kyphosis (PJK), which consists of a non-physiological abnormality in the sagittal plane that occurs following surgery in the segment proximal to the arthrodesis, is one of the postoperative complications that confronts the spine surgeon. In 1989, Bernhardt and Bridwell ${ }^{1}$ defined the segmental angulation, as measured by the Cobb method, of each level of the spine from T1T2 to L5S1. Then in 1999, Lee et al. ${ }^{2}$ defined abnormal PJK as kyphosis, measured from T2 to the proximal instrumented level, $\geq 5^{\circ}$ above the sum of the normal values of each segment as previously described by Bernhardt and Bridwell. ${ }^{1}$ In 2005 Glattes et al. ${ }^{3}$ modified the definition of PJK to a sagittal proximal junctional Cobb angle measured between the lower vertebral endplate of the uppermost instrumented vertebra (UIV) and the upper vertebral endplate of the 2 suprajacent vertebrae that is $\geq 10^{\circ}$ and at least $10^{\circ}$ greater than the preoperative measurement of the segment. In 2010 Helgeson et al. ${ }^{4}$ proposed another method to define PJK using the upper vertebral endplate of the adjacent vertebra and the lower vertebral endplate of the UIV as a basis. They suggested abnormality to be an angle more than two standard deviations greater than the normal segment, which in that case was $15^{\circ}$, and they redefined PJK as any increase in postoperative kyphosis $\geq 15^{\circ}$.

Currently there is no consensus around the definition of PJK, but that given by Glattes et al. ${ }^{3}$ is the most commonly used definition in the literature.

The main objective of this study was to analyze the prevalence of PJK in patients with neuromuscular scoliosis who underwent instrumented posterior spinal arthrodesis.

\section{METHODS}

In this retrospective, observational, epidemiological study, we analyzed 80 patients with neuromuscular scoliosis who had undergone spinal arthrodesis with instrumentation at a tertiary hospital between January 1, 2014 and December 31, 2016. Patient information related to the pathology, age, sex and surgical date, as well as panoramic spinal radiographs in a standing or sitting position taken preoperatively and in the 2nd and 24th months following surgery were collected from the database.

For the radiographic evaluation and PJK diagnosis we used the method proposed by Glattes et al., ${ }^{3}$ in which the sagittal proximal junctional Cobb angle (PJA), measured between the lower vertebral endplate of the uppermost instrumented vertebra (UIV) and the upper endplate of the two suprajacent vertebrae, measures $\geq 10^{\circ}$ and at least $10^{\circ}$ greater than the preoperative measurement of the segment. (Figure 1) The data were obtained from the electronic medical records archive. As the inclusion criterion, only patients diagnosed with neuromuscular scoliosis who were submitted consecutively to long posterior spinal arthrodesis with instrumentation between 01/01/2014 and 12/31/2016 who underwent adequate radiographical follow-up in the 2nd and 24th months were selected for this study. Patients who underwent posterior spinal arthrodesis without a diagnosis of neuromuscular scoliosis, as well as those previously submitted to spinal arthrodesis were excluded from the study.

Using the criteria mentioned above, we recorded which patients had proximal junctional kyphosis $\geq 10^{\circ}$ and progression of at least $10^{\circ}$ greater than the preoperative measurement in the 2nd and 24th months following surgery.
For the descriptive evaluations and analytical tests, SPSS version 20.0.0 software was used. The descriptive analyses included frequency, mean and median measurements. This study was submitted to the Institutional Review Board, which waived the informed consent form (ICF) requirement, and was approved as CAAE number 08114019.8.0000.0085.

\section{RESULTS}

A total of 39 individuals met the study inclusion criteria. Neuromuscular scolioses secondary to various pathologies were included in the study, as shown in Table 1. There was a predominance of male patients (58.87\%) (Table 2) and the minimum and maximum ages were 8 and 24 years, with a mean age of 14.05 years.

The minimum and maximum preoperative PJA values measured were $-14^{\circ}$ and $17^{\circ}$ (one of the cases of PJA measured was negative because the patient was lordotic) with a mean of $6.28^{\circ}$. (Table 3 ) After 2 years of postoperative follow-up, PJK was observed in 18 of the 39 patients (prevalence of $46.15 \%$ ) (Table 4). The incidence of PJK was lower at 2 months than at 2 years following surgery, with nine individuals in each group for incidences of $23.1 \%$ and $30 \%$, respectively. (Tables 5 and 6 )

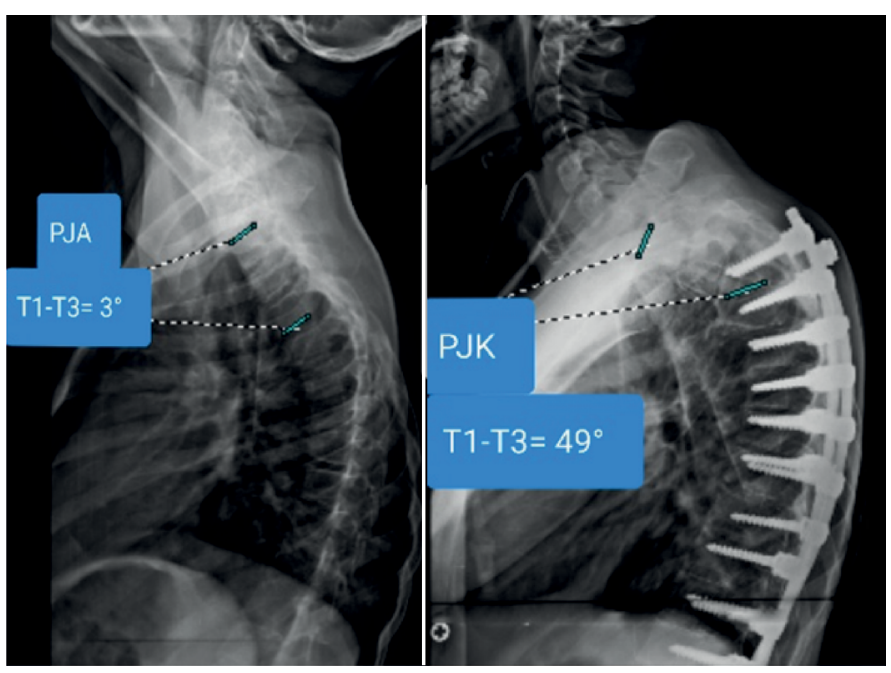

Figure 1. Preoperative proximal junctional angle on the left and progression to proximal junctional kyphosis on the right.

Table 1. Frequency by diagnosis.

\begin{tabular}{c|c|c|c|c}
\hline Diagnosis & Frequency & $\begin{array}{c}\text { Percentage } \\
(\%)\end{array}$ & Cumulative & $\begin{array}{c}\text { Cumulative } \\
\text { percentage (\%) }\end{array}$ \\
\hline $\begin{array}{c}\text { Congenital Muscular } \\
\text { Dystrophy }\end{array}$ & 2 & 5.128205 & 2 & 5.128205 \\
\hline Charcot Disease & 1 & 2.564103 & 3 & 7.692308 \\
\hline Myelomeningocele & 3 & 7.692308 & 6 & 15.384615 \\
\hline Central Core Myopathy & 1 & 2.564103 & 7 & 17.948718 \\
\hline Mitochondrial Myopathy & 1 & 2.564103 & 8 & 20.512821 \\
\hline Cerebral Palsy & 30 & 76.923077 & 38 & 97.435897 \\
\hline Leigh Syndrome & 1 & 2.564103 & 39 & 100 \\
\hline Total =39 & & & & \\
\hline
\end{tabular}


Table 2. Frequency by sex.

\begin{tabular}{c|c|c|c|c}
\hline Sex & Frequency & $\begin{array}{c}\text { Percentage } \\
\text { (\%) }\end{array}$ & Cumulative & $\begin{array}{c}\text { Cumulative } \\
\text { percentage (\%) }\end{array}$ \\
\hline female & 16 & 41.025641 & 16 & 41.025641 \\
\hline male & 23 & 58.974359 & 39 & 100 \\
\hline Total $=39$ & & & & \\
\hline
\end{tabular}

Table 3. Frequency of the preoperative PJA.

\begin{tabular}{c|c|c|c|c}
\hline Value & Frequency & Percentage (\%) & Cumulative & $\begin{array}{c}\text { Cumulative percentage } \\
\text { (\%) }\end{array}$ \\
\hline-14 & 1 & 2.564103 & 1 & 2.564103 \\
\hline 2 & 4 & 10.25641 & 5 & 12.820513 \\
\hline 3 & 2 & 5.128205 & 7 & 17.948718 \\
\hline 4 & 4 & 10.25641 & 11 & 28.205128 \\
\hline 5 & 6 & 15.384615 & 17 & 43.589744 \\
\hline 6 & 3 & 7.692308 & 20 & 51.282051 \\
\hline 7 & 2 & 5.128205 & 22 & 56.410256 \\
\hline 8 & 7 & 17.948718 & 29 & 74.358974 \\
\hline 9 & 4 & 10.25641 & 33 & 84.615385 \\
\hline 10 & 1 & 2.564103 & 34 & 87.179487 \\
\hline 12 & 4 & 10.25641 & 38 & 97.435897 \\
\hline 17 & 1 & 2.564103 & 39 & 100 \\
\hline \multicolumn{2}{r|}{ Total $=39$} & & & \\
\hline
\end{tabular}

Table 4. Prevalence of PJK two years following surgery

\begin{tabular}{c|c|c|c|c}
\hline PJK & Frequency & Percentage (\%) & Cumulative & $\begin{array}{c}\text { Cumulative percentage } \\
\text { (\%) }\end{array}$ \\
\hline $\mathrm{N}$ & 21 & 53.846154 & 21 & 53.846154 \\
\hline $\mathrm{Y}$ & 18 & 46.153846 & 39 & 100 \\
\hline \multicolumn{2}{c|}{ Total = 39 } & & & \\
\hline
\end{tabular}

Table 5. Incidence of PJK two months after surgery.

\begin{tabular}{c|c|c|c|c}
\hline PJK & Frequency & Percentage (\%) & Cumulative & $\begin{array}{c}\text { Cumulative percentage } \\
\text { (\%) }\end{array}$ \\
\hline $\mathrm{N}$ & 30 & 76.923076 & 30 & 76,9 \\
\hline $\mathrm{Y}$ & 9 & 23.076924 & 39 & 100 \\
\hline \multicolumn{2}{c|}{ Total 39} & & & \\
\hline
\end{tabular}

Table 6. Incidence of PJK two years after surgery.

\begin{tabular}{c|c|c|c|c}
\hline PJK & Frequency & Percentage (\%) & Cumulative & $\begin{array}{c}\text { Cumulative percentage } \\
(\%)\end{array}$ \\
\hline $\mathrm{N}$ & 21 & 70 & 21 & 30 \\
\hline $\mathrm{Y}$ & 9 & 30 & 30 & 100 \\
\hline \multicolumn{2}{c|}{ Total 30} & & & \\
\hline
\end{tabular}

The mean PJK angle at two months following surgery was $28.7^{\circ}$, with a minimum of $19^{\circ}$ and a maximum of $37^{\circ}$, and at two years following surgery was $26.3^{\circ}$, with a minimum of $11^{\circ}$ and a maximum of $54^{\circ}$.

\section{DISCUSSION}

PJK has been evaluated extensively over the years, both to define the diagnosis and to establish epidemiological values and risk factors for its appearance. However, most studies are conducted in patients with spinal deformities of various etiologies (AIS - adolescent idiopathic scoliosis, ASD - adult spinal deformity, Scheuermann's disease), which are not neuromuscular, or with early onset scoliosis (EOS), with very few of them conducted exclusively in patients with scoliosis of neuromuscular etiology.
Over the course of time, several studies have demonstrated a variance in the prevalence and incidence of PJK. In 1999, Lee et al. $^{2}$ reported a prevalence of PJK of $46 \%$ of the 69 patients treated surgically for AIS. Later studies clarified both risk factors and the prevalence and incidence of PJK in AIS, ASD and EOS. ${ }^{3-5} \mathrm{Kim}$ et al. ${ }^{6}$ showed that the prevalence of PJK after an average follow-up of 7.3 years was $26 \%$, with a diagnosis in $82 \%$ up to the second postoperative year and without significant progression after two years following surgery in patients with AIS, which was later corroborated by Kim et al. ${ }^{5}$ in a new study with 410 cases and a prevalence of $27 \%$. In the same way, similar results were observed by Glattes et al. ${ }^{3}$ and in other studies of ASD. ${ }^{7,8}$

In EOS, a prevalence of around $26 \%$, like that of PJK, was also confirmed in several other studies, both of patients treated with arthrodesis and with treatments using growth-guided devices. ${ }^{8-11}$ Chunda et al. ${ }^{12}$ reported a PJK prevalence of $11 \%$. But it was a meta-analysis of children and adolescents with spinal deformity of any etiology who had undergone surgical treatment. The emergence of PJK occurs in the first months ${ }^{13-15}$ and after the 2nd year following surgery there is little progression, with $66 \%$ of cases being diagnosed by the 3rd postoperative month and $80 \%$ within a year and a half following surgery. ${ }^{15}$

As mentioned previously, few studies have been conducted exclusively in patients with neuromuscular scoliosis and these show divergent prevalence and incidence rates. In 2003 and 2012, Sink et al. ${ }^{16}$ and Lonstein et al. ${ }^{17}$ published studies of patients with neuromuscular scoliosis, mainly cerebral palsy, reporting PJK in four of 41 and two of 93 patients studied, respectively.

This study showed a prevalence of PJK of $46.15 \%$ in patients with neuromuscular scoliosis who underwent corrective surgery with posterior spinal instrumentation, like the study conducted by Lee et al., ${ }^{2}$ but in patients with AIS. In relation to more recent studies,, $35-11$ which obtained a prevalence of around $26 \%$ in patients with AIS, ASD and EOS, the prevalence observed was higher. The incidence of PJK two months following surgery $(23.1 \%)$ was less than in the second postoperative year (30\%), there being nine individuals in each group, but in studies by Chen et al. ${ }^{13}$ and Lau et al. ${ }^{15}$ PJK was diagnosed in 66 to $90 \%$ of cases in the first three months following treatment, which differed from our PJK diagnosis results of $50 \%$ in the first two months following surgery. In the few studies conducted in patients with neuromuscular scoliosis, the prevalence of PJK was less than that found in our study, 12,16,17 although in these studies the patients analyzed were submitted to less rigid spinal instrumentation and the radiographic standards for a diagnosis of PJK were different than those used in our study.

\section{CONCLUSION}

The prevalence of PJK in patients with neuromuscular scoliosis was $46.15 \%$ two years after surgery. There was a difference in incidence in the 2nd and 24th postoperative months of $23.1 \%$ and $30 \%$, respectively, with the incidence of scoliosis in the 2nd month following surgery consistent with the other studies, although they were conducted with patients with AIS, ASD and EOS.

After conducting this study, we see the need for more research focused in the emergence of PJK in patients with neuromuscular scoliosis given the lack of recent studies with the new instrumentation materials in long posterior spinal arthrodesis and the conflicting results in the literature in relation to the prevalence of PJK.

All authors declare no potential conflict of interest related to this article.

CONTRIBUTION OF THE AUTHORS: Each author made significant individual contributions to this manuscript. RMF: writing, data collection and analysis, intellectual concept, preparation of the whole research project and review; KRBR: data collection and analysis; MLC: statistical analysis and review; IGV: writing and review; MIRN: statistical analysis and review; MAL: surgeries and review; AJR: surgeries and review; PTMC: surgeries, review and intellectual concept. 


\section{REFERENCES}

1. Bernhardt M, Bridwell $\mathrm{KH}$. Segmental analysis of the sagittal plane alignment of the normal thoracic and lumbar spines and thoracolumbar junction. Spine (Phila Pa 1976). $1989 ; 14(7): 717-21$.

2. Lee GA, Betz RR, Clements DH III, Huss GK. Proximal kyphosis after posterior spinal fusion in patients with idiopathic scoliosis. Spine (Phila Pa 1976). 1999;24(8): 795-9.

3. Glattes RC, Bridwell KH, Lenke LG, Kim YJ, Rinella A, Edwards C II. Proximal junctional kyphosis in adult spinal deformity following long instrumented posterior spinal fusion: Incidence, outcomes, and risk factor analysis. Spine (Phila Pa 1976). 2005:30(14):1643-9.

4. Helgeson MD, Shah SA, Newton PO, Clements DH 3rd, Betz RR, Marks MC. Evaluation of proximal junctional kyphosis in adolescent idiopathic scoliosis following pedicle screw, hook, or hybrid instrumentation. Spine (Phila Pa 1976). 2010;35(2):177-81.

5. Kim YJ, Lenke LG, Bridwell KH, Kim J, Cho SK, Cheh G. Proximal junctional kyphosis in adolescent idiopathic scoliosis after 3 different types of posterior segmental spinal instrumentation and fusions: Incidence and risk factor analysis of 410 cases. Spine (Phila Pa 1976). 2007:32(24):2731-8.

6. Kim YJ, Bridwell KH, Lenke LG, Kim J, Cho SK. Proximal junctional kyphosis in adolescent idiopathic scoliosis following segmental posterior spinal instrumentation and fusion: Minimum 5-year follow-up. Spine (Phila Pa 1976). 2005;30(18):2045-50.

7. Yagi M, Akilah KB, Boachie-Adjei O. Incidence, risk factors and classification of proximal junctional kyphosis: surgical outcomes review of adult idiopathic scoliosis. Spine (Phila Pa 1976). 2011:36(1):E60-8.

8. Cho SK, Kim YJ, Lenke LG. Proximal Junctional Kyphosis Following Spinal Deformity Surgery in the Pediatric Patient. J Am Acad Orthop Surg. 2015;23(7):408-14.

9. Li Y, Meryl G, Karlin L. Proximal junctional kyphosis after vertical expandable prosthetic titanium rib insertion. Spine Deform. 2013;1(6):425-33.
10. El-Hawary R, Sturm P, Cahill P, Samdani A, Vitale M, Gabos $P$, et al. What is the risk of developing proximal junctional kyphosis during growth friendly treatments for early-onset scoliosis? J Pediatr Orthop. 2017;37(2):86-91.

11. Watanabe K, Uno K, Suzuki T, Kawakami N, Tsuji T, Yanagida H, et al. Risk factors for proximal junctional kyphosis associated with dual-rod growing-rod surgery for early-onset scoliosis. J Spinal Disord Tech. 2016;29(8):E428-33.

12. Yan C, Li Y, Yu Z.. Prevalence and Consequences of the Proximal Junctional Kyphosis After Spinal Deformity Surgery: A Meta-Analysis. Medicine (Baltimore). 2016;95(20):e3471.

13. Chen X, Chen ZH, Qiu Y, Zhu ZZ, Li S, Xu L, et al. Proximal junctional kyphosis after posterior spinal instrumentation and fusion in young children with congenital scoliosis: a preliminary report on its incidence and risk factors. Spine (Phila Pa 1976). 2017;42(20):E1197-203.

14. Akbarnia BA, Emans JB. Complications of growth-sparing surgery in early onset scoliosis. Spine (Phila Pa 1976). 2010:35(25):2193-204.

15. Lau D, Clark AJ, Scheer JK, Daubs MD, Coe JD, Paonessa KJ, et al. Proximal junctional kyphosis and failure after spinal deformity surgery: a systematic review of the literature as a background to classification development. Spine (Phila Pa 1976). 2014;39(25):2093-102

16. Sink EL, Newton PO, Mubarak SJ, Wenger DR. Maintenance of sagittal plane alignment after surgical correction of spinal deformity in patients with cerebral palsy. Spine (Phila 1976). 2003;28(13):1396-403.

17. Lonstein JE, Koop SE, Novachek TF, Perra JH. Results and complications after spinal fusion for neuromuscular scoliosis in cerebral palsy and static encephalopathy using luque galveston instrumentation: experience in 93 patients. Spine (Phila Pa 1976). 2012;37(7):583-91. 